\title{
Nasiyyati M. \\ INVESTIGATION OF ONE LINEAR NON-SMOOTH TWO-PARAMETER DISCRETE OPTIMAL CONTROL PROBLEM
}

Об'єктом дослідження є лінійна задача оптимального управління, описувана дискретними двопараметричними системами при припущенні, що керований процес є ступінчастим.

Робота спрямована на виведення необхідних умов оптимальності першого порядку в разі негладкої функиї якості. А також на встановлення необхідних умов оптимальності другого порядку в східчастих задачах керування дискретними двопараметричними системами. В роботі досліджується одна лінійна двопараметрична дискретна задача оптимального управління з негладким критерієм якості. Обчислено спеціальний приріст функиіоналу якості. Розглянуто випадки за умови опуклої безлічі. Дано поняття особливого управління в досліджуваній задачі. Встановлено ряд необхідних умов оптимальності першого i другого порядків. А також отримані необхідні умови оптимальності другого порядку в термінах похідних за напрямками. У разі лінійного критерію якості за допомогою формули збільшення аналогічними міркуваннями доведена необхідна і достатня умова оптимальності. При припущенні, що безліч опукла, визначено спеціальний приріст критерію якості допустимого управління.

В ході дослідження використовувалися методи варіаційного обчислення і оптимального управління, теорії різнищевих рівнянь. Отримано результат для оптимальності особливого, периого порядку управління, в разі опуклості безлічі. Розглянуто випадок, коли функціонал, що мінімізується, є лінійним. В иьому випадку отримана необхідна і достатня умова для оптимальності допустимого управління.

Завдяки отриманим результатам дослідження забезпечується можливість отримання необхідних умов оптимальності першого порядку в термінах похідних за напрямками в ступінчастій задачі оптимального керування дискретними двопараметричними системами. А також необхідні умови оптимальності другого порядку в разі опуклості галузі управління і необхідні умови оптимальності особливих управлінь.

Отримані в роботі теоретичні результати представляють собою інтерес в теорії оптимального управління ступінчастими системами і можуть бути використані при подальшій розробиі теорії необхіднхх умов оптимальності для східчастих завдань управління.

Ключові слова: задача оптимального керування дискретними системами, необхідна умова оптимальності, особливе управління, негладкий функиіонал.

\section{Introduction}

Discrete dynamic models of controlled systems represent an important class of mathematical models both theoretically and in practice, which makes it possible to cover a very wide range of real objects. Among optimal control problems, an important place is occupied by optimal control problems described by discrete multidimensional and, in particular, two-parameter systems. Many real processes are described by multiparameter, and, in particular, twoparameter systems [1-3].

Discrete two-parameter systems are sometimes also called discrete 2-D systems [4-6]. Starting from the 70s of the XX century, various aspects of optimal control problems for discrete two-parameter systems have been intensively studied [7-9].

A number of image processing models in the state space are described by difference equations, which are a difference analogue of a system of second-order hyperbolic equations with Goursat - Darboux boundary conditions [10]. Such models are called Fornasini-Marquezini systems [11, 12]. Similar models are also used in the probabilistic description of images [13]. A number of optimal control problems for discrete two-parameter systems were studied, for example, in [14]. Therefore, the study of various discrete optimal control problems is relevant.

Thus, the object of research is the linear optimal control problem described by discrete two-parameter systems under the assumption that the controlled process is stepwise. The considered difference system of equations is a discrete analogue of a linear hyperbolic equation with Goursat boundary conditions. Moreover, it is considered that the minimized, terminal type, functional is non-smooth. And the aim of research is finding sufficient and necessary conditions under various conditions of optimality.

\section{Methods of research}

Let's consider the minimum functional of the terminal functional: 


$$
S(u)=\sum_{i=1}^{2} \Phi_{i}\left(z_{i}\left(t_{i}, X\right)\right)
$$

under restrictions:

$$
\begin{aligned}
& u_{i}(t, x) \in U_{i} \subset R^{r_{i}},(t, x) \in D_{i}, i=1,2, \\
& z_{i}(t+1, x+1)=A_{i}(t, x) z_{i}(t, x)+B_{i}(t, x) z_{i}(t+1, x)+ \\
& +C_{i}(t, x) z_{i}(t, x+1)+f_{i}\left(t, x, u_{i}(t, x)\right), i=1,2 \\
& z_{1}\left(t_{0}, x\right)=\alpha(x), x=x_{0}, x_{0}+1, \ldots, X, \\
& z_{1}\left(t, x_{0}\right)=\beta_{1}(t), t=t_{0}, t_{0}+1, \ldots, t_{1}, a\left(x_{0}\right)=\beta_{1}\left(t_{0}\right), \\
& z_{2}\left(t_{1}, x\right)=G(x) z_{1}\left(t_{1}, x\right), x=x_{0}, x_{0}+1, \ldots, X \\
& z_{2}\left(t, x_{0}\right)=\beta_{2}(t), t=t_{1}, t_{1}+1, \ldots, t_{2}, \\
& \beta_{2}\left(t_{1}\right)=G\left(x_{0}\right) z_{1}\left(t_{1}, x_{0}\right),
\end{aligned}
$$

where $\Phi_{i}\left(z_{i}\right), i=1,2$ - the specified scalar functions having derivatives in directions up to the second order inclusive; $A_{i}(t, x), B_{i}(t, x), C_{i}(t, x), i=1,2-$ given, $\left(n_{i} \times n_{i}\right), i=1,2$-dimensional matrix functions, respectively; $f_{i}\left(t, x, u_{i}\right), i=1,2-$ given, $n_{i}, i=1$, 2-dimensional vector functions continuous in the totality of variables; $G(x)$ - given discrete matrix function; $\alpha(x), \beta_{1}(t), \beta_{2}(t)$ - given discrete vector functions of the corresponding dimensions; $U_{i}, i=1,2$ - given nonempty and bounded sets; $u_{i}(t, x), i=1,2-r_{i}$-dimensional discrete vector functions; $\Phi_{\mathrm{i}}(t), i=1,2$ - given scalar functions having derivatives in any direction up to and including second order; $R^{r_{i}}-r_{i}$-dimensional linear real space; $R^{r_{i}}-r_{i}$-dimensional rectangle; $t_{0}, t_{1}, t_{2}, x_{0}, X$ - given parameters.

Let's note that the functions $\Phi_{i}\left(z_{i}\right), i=1,2$ are not required to fulfill the Lipschitz condition.

A pair $u(t, x)=\left(u_{1}(t, x), u_{2}(t, x)\right)$ with the above properties is called an admissible control, and $z(t, x)=\left(z_{1}(t, x), z_{2}(t, x)\right)-$ an admissible state.

Here let's obtain the necessary optimality conditions for the first and second orders in terms of directional derivatives $[15,16]$. In the case of a linear quality criterion, a necessary and sufficient optimality condition is proved.

\section{Research results and discussion}

3.1. Increment formula and necessary optimality conditions. Let $(u(t, x), z(t, x))$ is a fixed valid process. Let's denote by $(\bar{u}(t, x)=u(t, x)+\Delta u(t, x), \bar{z}(t, x)=z(t, x)+\Delta z(t, x))$ an arbitrary process. Then it is clear that the state $z(t, x)$ increment $\Delta z(t, x)$ will be the solution to the following problem:

$$
\begin{aligned}
& \Delta z_{i}(t+1, x+1)=A_{i}(t, x) \Delta z_{i}(t, x)+ \\
& +B_{i}(t, x) \Delta z_{i}(t+1, x)+C_{i}(t, x) \Delta z_{i}(t, x+1)+ \\
& +\left[f_{i}\left(t, x, \bar{u}_{i}(t, x)\right)-f_{i}\left(t, x, u_{i}(t, x)\right)\right], i=1,2, \\
& \Delta z_{1}\left(t_{0}, x\right)=0, x=x_{0}, x_{0}+1, \ldots, X, \\
& \Delta z_{1}\left(t, x_{0}\right)=0, t=t_{0}, t_{0}+1, \ldots, t_{1}, \\
& \Delta z_{2}\left(t_{1}, x\right)=G(x) \Delta z_{1}\left(t_{1}, x\right), x=x_{0}, x_{0}+1, \ldots, X, \\
& \Delta z_{2}\left(t, x_{0}\right)=0, t=t_{1}, t_{1}+1, \ldots, t_{2} .
\end{aligned}
$$

By $R_{i}(t, x ; \tau, s), i=1,2$ let's denote $\left(n_{i} \times n_{i}\right), i=1,2$ matrix function, which is the solution of the matrix difference system:

$$
\begin{aligned}
& R_{i}(t, x ; \tau-1, s-1)=R_{i}(t, x ; \tau, s) A_{i}(\tau, s)+ \\
& +B_{i}(\tau-1, s) R_{i}(t, x ; \tau-1, s)+C_{i}(\tau, s-1) R_{i}(t, x ; \tau, s-1),
\end{aligned}
$$

with boundary conditions:

$$
\begin{aligned}
& R_{i}(t, x ; \tau-1, x-1)=R_{i}(t, x ; \tau, x-1) C_{i}(\tau, x-1), \\
& R_{i}(t, x ; t-1, s-1)=R_{i}(t, x ; t-1, s) B_{i}(t-1, s), \\
& R_{i}(t, x ; t-1, x-1)=E_{i} .
\end{aligned}
$$

Then the solution of the boundary value problem (5), (6) by analogy [14] can be represented as:

$$
\begin{aligned}
& \Delta z_{1}(t, x)=\sum_{\tau=t_{0}}^{t-1} \sum_{s=x_{0}}^{x-1} R_{1}(t, x ; \tau, s) \Delta_{\bar{u}_{1}(\tau, s)} f_{1}[\tau, s], \\
& \Delta z_{2}(t, x)=\sum_{\tau=t_{1}}^{t-1} \sum_{s=x_{0}}^{x-1} R_{2}(t, x ; \tau, s) \Delta_{v_{2}(\tau, s)} f_{2}[\tau, s]+ \\
& +R_{2}\left(t, x ; t_{1}-1, x-1\right) z_{2}\left(t_{1}, x\right)+ \\
& +\sum_{s=x_{0}}^{x-1}\left[\begin{array}{l}
R_{2}\left(t, x ; t_{1}-1, s-1\right)- \\
-R_{2}(t, x ; t-1, s) A_{2}(t-1, s)
\end{array}\right] \Delta z_{2}\left(t_{1}, s\right) .
\end{aligned}
$$

In view of (9) from (10) let's have:

$$
\begin{aligned}
& \Delta z_{2}(t, x)=\sum_{\tau=t_{1}}^{t-1} \sum_{s=x_{0}}^{x-1} R_{2}(t, x ; \tau, s) \Delta_{v_{2}(\tau, s)} f_{2}[\tau, s]+ \\
& +\sum_{\tau=t_{0}}^{t_{1}-1} \sum_{s=x_{0}}^{x-1} R_{2}\left(t, x ; t_{1}-1, x-1\right) G(x) R_{1}\left(t_{1}, x ; \tau, s\right) \Delta_{\bar{u}_{1}(\tau, s)} f_{1}[\tau, s]+ \\
& +\sum_{s=x_{0}}^{x-1}\left[R_{2}\left(t, x ; t_{1}-1, s-1\right)-R_{2}\left(t, x ; t_{1}-1, s\right) A_{2}(t-1, s)\right] G(s) \times \\
& \times\left[\sum_{\tau=t_{0}}^{t_{1}-1} \sum_{\beta=x_{0}}^{x-1} R_{2}\left(t_{1}, s ; \tau, \beta\right) \Delta_{\bar{u}_{1}(\tau, \beta)} f_{1}[\tau, \beta]\right] .
\end{aligned}
$$

Assuming:

$$
\begin{aligned}
& \Omega(t, x ; \tau, s)=R_{2}\left(t, x ; t_{1}-1, x-1\right) G(x) R_{1}\left(t_{1}, x ; \tau, s\right)+ \\
& +\sum_{\beta=s+1}^{x-1}\left[\begin{array}{l}
R_{2}\left(t, x ; t_{1}-1, \beta-1\right)- \\
-R_{2}\left(t, x ; t_{1}-1, \beta\right) A_{2}\left(t_{1}-1, s\right)
\end{array}\right] G(\beta) R_{1}\left(t_{1}, \beta ; \tau, s\right),
\end{aligned}
$$

the above representation is written as:

$$
\begin{aligned}
& \Delta z_{2}(t, x)=\sum_{\tau=t_{0}}^{t_{1}-1} \sum_{s=x_{0}}^{x-1} \Omega(t, x ; \tau, s) \Delta_{\bar{u}_{1}(\tau, s)} f_{1}[\tau, s]+ \\
& +\sum_{\tau=t_{1}}^{t-1} \sum_{s=x_{0}}^{x-1} R_{2}(t, x ; \tau, s) \Delta_{\bar{\tau}_{2}(\tau, s)} f_{2}[\tau, s] .
\end{aligned}
$$

From this it is clear that:

$$
\begin{aligned}
& \Delta z_{1}\left(t_{1}, X\right)=\sum_{t=t_{0}}^{t_{1}-1} \sum_{x=x_{0}}^{X-1} R_{1}\left(t_{1}, X ; t, x\right) \Delta_{\bar{u}_{1}(t, x)} f_{1}[t, x], \\
& \Delta z_{2}\left(t_{2}, X\right)=\sum_{t=t_{0}}^{t_{1}-1} \sum_{x=x_{0}}^{X-1} \Omega\left(t_{2}, X ; t, x\right) \Delta_{\bar{u}_{1}(t, x)} f_{1}[t, x]+ \\
& +\sum_{\tau=t_{0}}^{t_{2}-1} \sum_{s=x_{0}}^{X-1} R_{2}\left(t_{2}, X ; \tau, s\right) \Delta_{\bar{u}_{2}(\tau, s)} f_{2}[\tau, s] .
\end{aligned}
$$


Let's assume the sets:

$$
f_{i}\left(t, x, U_{i}\right)=\left\{\alpha_{i} \in R^{\gamma_{i}}: \alpha_{i}=f_{i}\left(t, x, v_{i}\right), v_{i} \in U\right\}, i=1,2,
$$

convex for all $(t, x)$.

The special increment of permissible control $u(t, x)=$ $=\left(u_{1}(t, x), u_{2}(t, x)\right)^{\prime}$ is determined by the formula:

$$
\left\{\begin{array}{l}
\Delta u_{1}(t, x ; \varepsilon)=v_{1}(t, x ; \varepsilon)-u_{1}(t, x),(t, x) \in D_{1}, \\
\Delta u_{2}(t, x ; \varepsilon)=0,(t, x) \in D_{2},
\end{array}\right.
$$

where $\varepsilon \in[0,1]$ is an arbitrary number, and, $v_{1}(t, x ; \varepsilon) \in U_{1}$, $(t, x) \in D_{1}$ is an arbitrary admissible control such that:

$$
\Delta_{v_{1}(t, x ; \varepsilon)} f_{1}(t, x)=\varepsilon \Delta_{v_{1}(t, x)} f_{1}[t, x] .
$$

(This is possible due to the convexity of the set (14)) Let's denote by $\Delta z(t, x ; \varepsilon)=\left(\Delta z_{1}(t, x ; \varepsilon), \Delta z_{2}(t, x ; \varepsilon)\right)$ the special state increment $z(t, x)=\left(z_{1}(t, x), z_{2}(t, x)\right)$ corresponding to the control increment (15).

From the representations (13) it is clear that:

$$
\begin{aligned}
& \Delta z_{1}\left(t_{1}, X ; \varepsilon\right)=\varepsilon \sum_{t=t_{0}}^{t_{1}-1} \sum_{x=x_{0}}^{X-1} R_{1}\left(t_{1}, X ; t, x\right) \Delta_{v_{1}(t, x)} f_{1}[t, x], \\
& \Delta z_{2}\left(t_{2}, X ; \varepsilon\right)=\varepsilon \sum_{t=t_{0}}^{t_{1}-1} \sum_{x=x_{0}}^{X-1} \Omega\left(t_{2}, X ; t, x\right) \Delta_{v_{1}(t, x)} f_{1}[t, x] .
\end{aligned}
$$

Assuming that:

$$
\begin{aligned}
& \ell_{1}\left(v_{1}\right)=\sum_{t=t_{0}} \sum_{x=x_{0}}^{t_{1}-1} R_{1}\left(t_{1}, X ; t, x\right) \Delta_{v_{1}(t, x)} f_{1}[t, x], \\
& \ell_{2}\left(v_{2}\right)=\sum_{t=t_{0}}^{t_{1}-1} \sum_{x=x_{0}}^{X-1} \Omega\left(t_{2}, X ; t, x\right) \Delta_{v_{1}(t, x)} f_{1}[t, x] .
\end{aligned}
$$

Let's calculate the special increment of the quality functional taking into account the expressions for $\ell_{i}\left(v_{1}\right)$, $i=1,2$ :

$$
\begin{aligned}
& \Delta S_{\varepsilon}(u(t, x))=S(u(t, x)+\Delta u(t, x ; \varepsilon))-S(u(t, x))= \\
& =\sum_{i=1}^{2}\left[\Phi_{i}\left(z_{i}\left(t_{i}, X\right)+\Delta z_{i}\left(t_{i}, X ; \varepsilon\right)\right)-\Phi_{i}\left(z_{i}\left(t_{i}, X\right)\right)\right]= \\
& =\left[\Phi_{1}\left(z_{1}\left(t_{1}, X\right)+\varepsilon \ell_{1}\left(v_{1}\right)\right)-\Phi_{1}\left(z_{1}\left(t_{1}, X\right)\right)\right]+ \\
& +\left[\Phi_{2}\left(z_{2}\left(t_{2}, X\right)+\varepsilon \ell_{2}\left(v_{1}\right)\right)-\Phi_{2}\left(z_{1}\left(t_{1}, X\right)\right)\right] .
\end{aligned}
$$

Hence, taking into account the works, for example, $[15,16]$ :

$$
\begin{aligned}
& \Delta S_{\varepsilon}(u(t, x))= \\
& =\varepsilon \sum_{i=1}^{2} \frac{\partial \Phi_{i}\left(z_{i}\left(t_{i}, X\right)\right)}{\partial \ell_{i}\left(v_{1}\right)}+\frac{\varepsilon^{2}}{2} \sum_{i=1}^{2} \frac{\partial^{2} \Phi_{i}\left(z_{i}\left(t_{i}, X\right)\right)}{\partial \ell_{i}\left(v_{1}\right)^{2}}+\mathrm{o}\left(\varepsilon^{2}\right) .
\end{aligned}
$$

From the expansion (17) it immediately follows that:

$$
\sum_{i=1}^{2} \frac{\partial \Phi_{i}\left(z_{i}\left(t_{i}, X\right)\right)}{\partial \ell_{i}\left(v_{1}\right)} \geq 0
$$

Further, by analogy with (15):

$$
\left\{\begin{array}{l}
\Delta u_{1}(t, x ; \mu)=0,(t, x) \in D_{1}, \\
\Delta u_{2}(t, x ; \mu)=v_{2}(t, x ; \mu)-u_{2}(t, x),(t, x) \in D_{2},
\end{array}\right.
$$

where $\mu \in[0,1]$ is an arbitrary number, and $v_{2}(t, x ; \varepsilon) \in U_{2}$, $(t, x) \in D_{2}$ is an arbitrary number is such that:

$$
\Delta_{v_{2}(t, x ; \mu)} f_{2}[t, x]=\mu \Delta_{v_{2}(t, x)} f_{2}[t, x],
$$

where $v_{2}(t, x) \in U,(t, x) \in D_{2}$ is an arbitrary admissible control corresponding to the control $v_{2}(t, x ; \mu)$.

Let's denote by $\Delta z(t, x ; \mu)=\left(\Delta z_{1}(t, x ; \mu), \Delta z_{2}(t, x ; \mu)\right)$ the special state increment $z(t, x)=\left(z_{1}(t, x), z_{2}(t, x)\right)$. From the representations (9), (12) it is clear that:

$$
\left\{\begin{array}{l}
\Delta z_{1}(t, x ; \mu)=0, \quad(t, x) \in D_{1} \cup\left(t_{1}, X\right), \\
\Delta z_{2}(t, x)=\mu \sum_{\tau=t_{1}}^{t-1} \sum_{s=x_{0}}^{x-1} R_{2}(t, x ; \tau, s) \Delta_{v_{2}(\tau, s)} f_{2}[\tau, s] .
\end{array}\right.
$$

Assuming that:

$$
\ell_{3}\left(v_{2}\right)=\sum_{\tau=t_{0}}^{t_{2}-1} \sum_{s=x_{0}}^{X-1} R_{2}\left(t_{2}, X ; \tau, s\right) \Delta_{v_{2}(\tau, s)} f_{2}[\tau, s],
$$

and calculate the special increment of the quality criterion:

$$
\begin{aligned}
& \Delta S_{\mu}(u(t, x))=S(u(t, x)+\Delta u(t, x ; \mu))-S(u(t, x))= \\
& =\Phi_{2}\left(z_{2}\left(t_{2}, X\right)+\Delta z_{2}\left(t_{2}, X ; \mu\right)\right)-\Phi_{2}\left(z_{2}\left(t_{2}, X\right)\right)= \\
& =\Phi_{2}\left(z_{2}\left(t_{2}, X\right)+\mu \ell_{3}\left(v_{2}\right)\right)-\Phi_{2}\left(z_{2}\left(t_{2}, X\right)\right)= \\
& =\mu \frac{\partial \Phi_{2}\left(z_{2}\left(t_{2}, X\right)\right)}{\partial \ell_{3}\left(v_{2}\right)}+\frac{\mu^{2}}{2} \frac{\partial^{2} \Phi_{2}\left(z_{2}\left(t_{2}, X\right)\right)}{\partial \ell_{3}^{2}\left(v_{2}\right)}+o\left(\mu^{2}\right) .
\end{aligned}
$$

For sufficiently small, it follows from expansion (22) that along the optimal process $(u(t, x), z(t, x))$ :

$$
\frac{\partial \Phi_{2}\left(z_{2}\left(t_{2}, X\right)\right)}{\partial \ell_{3}\left(v_{2}\right)} \geq 0
$$

Let's state the result:

Theorem 1. If the sets (14) are convex, then for the optimality of the admissible control $u(t, x)=\left(u_{1}(t, x), u_{2}(t, x)\right)$ in problem $(6)-(9)$ it is necessary that relations $(18),(23)$ hold for all $v_{1}(t, x) \in U_{1},(t, x) \in D_{1}$ and $v_{2}(t, x) \in U_{2},(t, x) \in D_{2}$, respectively.

Let's give the concept of special control in the problem under consideration.

Definition 1. Let's call an admissible control $u(t, x)=$ $=\left(u_{1}(t, x), u_{2}(t, x)\right)$ a special first-order control in problem (1)-(5) if, for all $v_{1}(t, x) \in U_{1},(t, x) \in D_{1}$ and $v_{2}(t, x) \in U_{2}$, $(t, x) \in D_{2}$, the relations are performed:

$$
\sum_{i=1}^{2} \frac{\partial \Phi_{i}\left(z_{i}\left(t_{i}, X\right)\right)}{\partial \ell_{i}\left(v_{1}\right)} \equiv 0, \frac{\partial \Phi_{2}\left(z_{2}\left(t_{2}, X\right)\right)}{\partial \ell_{3}\left(v_{2}\right)}=0 .
$$

When conditions (24) are satisfied, it follows from expansions (17), (22), respectively, that:

$$
\sum_{i=1}^{2} \frac{\partial^{2} \Phi_{i}\left(z_{i}\left(t_{i}, X\right)\right)}{\partial \ell_{i}^{2}\left(v_{1}\right)} \geq 0,
$$




$$
\frac{\partial^{2} \Phi_{2}\left(z_{2}\left(t_{2}, X\right)\right)}{\partial \ell_{3}^{2}\left(v_{2}\right)} \geq 0 .
$$

Theorem 2. For optimality of a special, first-order control $u(t, x)=\left(u_{1}(t, x), u_{2}(t, x)\right)$ in problem (1)-(4) in the case of convexity of set (14), it is necessary that inequalities (25), (26) hold for all $v_{1}(t, x) \in U_{1},(t, x) \in D_{1}$ and $v_{2}(t, x) \in U_{2}$, $(t, x) \in D_{2}$, respectively.

Inequalities (25), (26) are necessary conditions for second-order optimality in terms of directional derivatives.

3.2. A necessary and sufficient optimality condition. Let's suppose that in problem (5), (6) the minimized functional is linear, i. e.:

$$
S(u)=\sum_{i=1}^{2} g_{i}^{\prime} z_{i}\left(t_{i}, X\right)
$$

where $i=1,2$ are given, $n_{i}, i=1,2$-dimensional, respectively, constant vectors.

In this case, the increment of the quality criterion (27) is written in the form:

$$
\Delta S(u)=\sum_{i=1}^{2} g_{i}^{\prime} \Delta z_{i}\left(t_{i}, X\right)
$$

Taking into account the representations (9)-(12), from here let's have:

$$
\begin{aligned}
& \Delta S(u)=\sum_{t=t_{0}}^{t_{1}-1} \sum_{x=x_{0}}^{X-1} g_{1}^{\prime} R_{1}\left(t_{1}, X, t, x\right) \Delta_{\bar{u}_{1}(t, x)} f_{1}[t, x]+ \\
& +\sum_{t=t_{0}}^{t_{1}-1} \sum_{x=x_{0}}^{X-1} g_{2}^{\prime} \Omega\left(t_{2}, X, t, x\right) \Delta_{\bar{u}_{1}(t, x)} f_{1}[t, x]+ \\
& +\sum_{t=t_{1}}^{t_{2}-1} \sum_{x=x_{0}}^{X-1} g_{2}^{\prime} R_{2}\left(t_{2}, X ; t, x\right) \Delta_{\bar{u}_{2}(t, x)} f_{2}[t, x]= \\
& =\sum_{t=t_{0}}^{t_{1}-1} \sum_{x=x_{0}}^{X-1}\left[g_{1}^{\prime} R_{1}\left(t_{1}, X ; t, x\right)+g_{2}^{\prime} \Omega_{1}\left(t_{2}, X, t, x\right)\right] \times \\
& \times \Delta_{\bar{u}_{1}(t, x)} f_{1}[t, x]+\sum_{t=t_{1}}^{t_{2}-1} \sum_{x=x_{0}}^{X-1} g_{2}^{\prime} R_{2}\left(t_{2}, X ; t, x\right) \Delta_{\bar{u}_{2}(t, x)} f_{2}[t, x] .
\end{aligned}
$$

Assuming that:

$$
\begin{aligned}
& H_{i}\left(t, x, u_{i}, \psi_{i}\right)=\psi_{i}^{\prime} f_{i}\left(t, x, u_{i}\right), \quad i=1,2, \\
& \psi_{1}(t, x)=-R_{1}^{\prime}\left(t_{1}, X ; t, x\right) g_{1}-\Omega_{1}^{\prime}\left(t_{2}, X, t, x\right) g_{2}, \\
& \psi_{2}(t, x)=-R_{2}^{\prime}\left(t_{2}, X ; t, x\right) g_{2} .
\end{aligned}
$$

Then the increment formula is written as:

$$
\begin{aligned}
& \Delta S(u)=-\sum_{t=t_{0}}^{t_{1}-1} \sum_{x=x_{0}}^{X-1} \Delta_{\bar{u}_{1}(t, x)} H_{1}\left(t, x, z_{1}^{0}(t, x), u_{1}^{0}(t, x), \psi_{1}^{0}(t, x)\right)- \\
& -\sum_{t=t_{1}}^{t_{2}-1} \sum_{x=x_{0}}^{X-1} \Delta_{\bar{u}_{2}(t, x)} H_{2}\left(t, x, z_{2}^{0}(t, x), u_{2}^{0}(t, x), \psi_{2}^{0}(t, x)\right) .
\end{aligned}
$$

Using the increment formula (29) by arguments similar to those from [14], it is proved.

Theorem 3. For the optimality of the admissible control $(u(t, x), z(t, x))$ in problem (1)-(4), (27), it is necessary and sufficient that the inequality:

$$
\begin{aligned}
& \sum_{t=t_{0}}^{t_{1}-1} \sum_{x=x_{0}}^{X-1} \Delta_{v_{1}(t, x)} H_{1}\left(t, x, z_{1}(t, x), u_{1}(t, x), \psi_{1}(t, x)\right) \leq 0, \\
& \sum_{t=t_{1}}^{t_{2}-1} \sum_{x=x_{0}}^{X-1} \Delta_{v_{2}(t, x)} H_{2}\left(t, x, z_{2}(t, x), u_{2}(t, x), \psi_{2}(t, x)\right) \leq 0,
\end{aligned}
$$

are performed accordingly for all $v_{1}(t, x) \in U_{1}, \quad(t, x) \in D_{1}$, $v_{2}(t, x) \in U_{2},(t, x) \in D_{2}$.

\section{Conclusions}

In the present paper, let's consider the case of degeneracy of the obtained necessary optimality condition and establish the necessary second-order optimality conditions in terms of directional derivatives.

A necessary and sufficient optimality condition is obtained. And also, assuming the linearity of the quality functional, the necessary and sufficient optimality condition in the form of a discrete maximum condition is proved.

The results of the work can find application in various fields of the modern theory of optimal control, as well as in the study of specific problems of optimal control.

\section{References}

1. Gaishun, I. V., Hoang, V. Q. (1991). Conditions for complete controllability and observability of discrete two-parameter systems. Differ. Equ., 27 (2), 125-130.

2. Kaczorek, T. (1985). Two-Dimensional Linear Systems. Springer, 399. doi: https://doi.org/10.1007/bfb0005617

3. Fornasini, E., Marchesini, G. (1976). State-space realization theory of two-dimensional filters. IEEE Transactions on Automatic Control, 21 (4), 484-492. doi: https://doi.org/10.1109/tac.1976.1101305

4. Afkhami, H., Argha, A., Roopaei, M., Ahrari Nouri, M. (2011). Optimal Iterative Learning Control Method for 2-D Systems using 1-D Model (WAM) of 2-D Systems. World Applied Sciences Journal, 13 (11), 2410-2419.

5. Nyman, P.-O. (2009). Hierarchical least squares optimal control of 2-D systems. 2009 American Control Conference. doi: https:// doi.org/10.1109/acc.2009.5160019

6. Rogers, E., Galkowski, K., Owens, D. H. (2007). Control Systems Theory and Applications for Linear Repetitive Processes. Springer. doi: https://doi.org/10.1007/978-3-540-71537-5

7. Kaczorek, T. (2005). Controllability and minimum energy control of positive 2D systems with delays. Control and Cybernetics, 34 (2), 411-423.

8. Kaczorek, T. (1991). Some recent results in singular 2-D systems theory. Kybernetika, 27 (3), 253-262.

9. Przyborowski, P., Kaczorek, T. (2009). Positive 2D DiscreteTime Linear Lyapunov Systems. International Journal of Applied Mathematics and Computer Science, 19 (1), 95-106. doi: https:// doi.org/10.2478/v10006-009-0009-3

10. Gayshun, I. V. (1996). Mnogoparametricheskie sistemy upravleniya. Minsk: Nauka i tehnika, 200.

11. Bisiacco, M., Fornasini, E. (1990). Optimal Control of TwoDimensional Systems. SIAM Journal on Control and Optimization, 28 (3), 582-601. doi: https://doi.org/10.1137/0328035

12. Fornasini, E., Marchesini, G. (1976). State-space realization theory of two-dimensional filters. IEEE Transactions on Automatic Control, 21 (4), 484-492. doi: https://doi.org/10.1109/tac.1976.1101305

13. Prett, U. (1982). Tsifrovaya obrabotka izobrazheniy. Vol. I, II. Moscow: Nauka.

14. Mansimov, K. B. (2013). Diskretnye sistemy. Baku: Izd-vo BGU, 151.

15. Dem'yanov, V. F. (1974). Minimaks: Differentsiruemost' po napravleniyam. Leningrad: Izd-vo LGU, 120.

16. Dem'yanov, V. F., Rubinov, A. M. (1990). Osnovy negladkogo analiza i kvazi-differentsial'noe ischislenie. Moscow: Nauka, 432.

Nasiyyati Mehriban, PhD, Researcher, Laboratory of Control in Complex Dynamic Systems, Institute of Control Systems of Azerbaijan National Academy of Sciences, Baku, Azerbaijan, ORCID: https://orcid.org/0000-0002-8512-6942,e-mail:nasiyati_m@mail.ru 